\section{Identification of UV Photoproducts and Hydrolysis Products of Butachlor by Mass Spectrometry}

HE-HUI ZHENG AND CHANG-MING YE* Research Center for Eco-Environmental Science, Chinese Academy of Sciences, P.O. Box 2871, Beijing 100085, P.R. China

The photoproducts and hydrolysis products of butachlor in water were identified by gas chromatography/mass spectrometry. When exposed to UV light, butachlor in aqueous solution was rapidly degraded, giving at least 11 photoproducts as a result of dechlorination with subsequent hydroxylation or cyclization processes. The chemical structures of nine degradation compounds were identified on the basis of mass spectrum interpretation and literature data. Major photoproducts are identified as 8-ethyl-1butoxymethyl-4-methyl-2-oxo-1,2,3,4-tetrahydro-quinoline, 2-hydroxy-2',6'-diethyl- $N$-(butoxymethyl) acetanilide, and a compound related to butachlor. Minor photoproducts are identified as 2,6-diethylaniline; 1-acetyl-7-ethylindole; $N$-(2,6-diethylphenyl)- $N$-(butoxymethyl)ac etamide; 2-oxo- $N$ (2,6-diethyl-phenyl)- $N$-(butoxymethyl)ac etamide; 1-hydroxyacetyl-2-butoxyl-3-methyl-7-ethylindole; 1-acetyl-2butoxyl-3- methyl-7-ethylindole; and two compounds with the chemical structure unknown. The half-lives of butachlor UV photolysis were $7.54,10.56$, and $12.22 \mathrm{~min}$ in deionized water, river water, and paddy water, respectively. The halflives of butachlor hydrolysis at $\mathrm{pH} 4,7$, and 10 were 630,1155 , and 1155 days at $25 \pm 1^{\circ} \mathrm{C}$, respectively. A hydrolysis product at pH 4 was identified by GC/MS to be 2-hydroxy$2^{\prime}, 6^{\prime}$-diethyl- $N$-(butoxymethyl) acetanilide.

\section{Introduction}

Butachlor [2-chloro-N-(2,6-diethylphenyl)- N-(butoxymethyl)acetamide] (Figure 1), a chloracetamide herbicide, is a germination inhibitor used widely for weed control of grasses in rice. More than $5.0 \times 10^{6} \mathrm{~kg}$ of butachlor (active ingredient) is applied annually in China (1-2). It is the most heavily used agricultural herbicide in rice fields in China.

There is little information in the open literature on the occurrence of butachlor. Moreinformation is required on its occurrence in water, its toxicity to aquatic organisms, its persistence, and its environmental fatein order to assess the hazards of butachlor use to aquatic ecosystems. Chen et al. (3-4) reported the photodegradation of butachlor. When exposed to UV light, thin films of butachlor were rapidly degraded, giving at least seven products on thin-layer and gas chromatograms. One was identified as 2-chloro- 2 ', 6'diethylacetanilide and three others were assumed to be 2-hydroxyl-2',6'-diethyl-N-(butoxymethyl)-acetanilide, 1chloroacetyl-2,3-dihydo-7-ethylindole, and N-2,6-diethylphenyl-2,5-dihydroxazol-4-one. Under UV or sunlight irradiation in aqueous solution, butachlor underwent more

\footnotetext{
* Correspondingauthor phone: +86106292-3207; fax: 62923563;
} e-mail: yechm@mail.rcees.ac.cn.

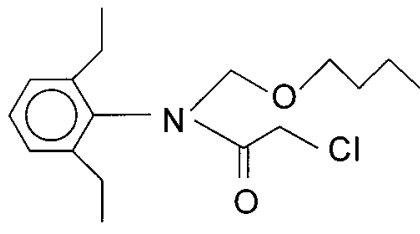

FIGURE 1. Chemical structure of butachlor (2-chloro-N-(2,6diethylphenyl)- $N$-(butoxymethyl) acetamide).

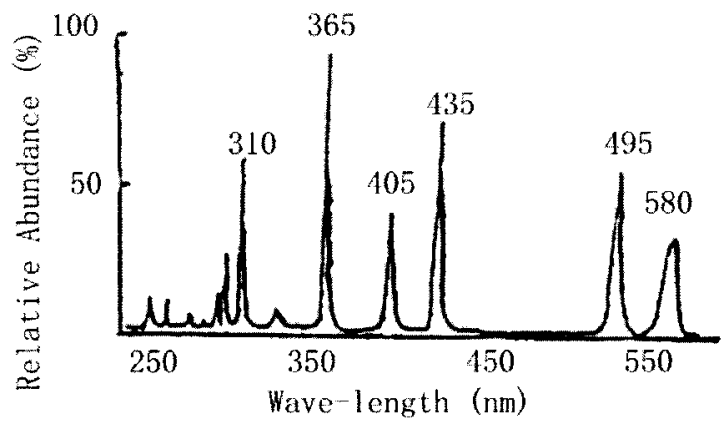

FIGURE 2. Emssion spectra of medium-pressure quart mercury vapor lamp.

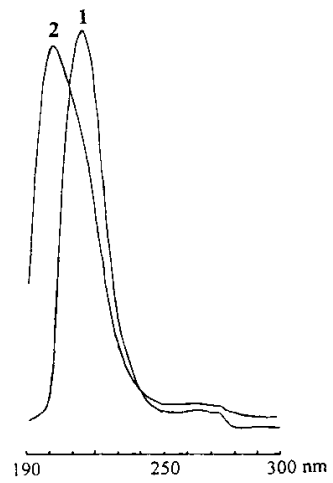

FIGURE 3. Butachlor adsorption spectrogram. Peaks: 1, in the methanol solution; 2 , in the $w$ ater solution.

complex decomposition than it did as a thin film, and gave at least 24 products. Four of them were identified as 2-chloro2',6'-diethylacetanilide, 2,6-diethylanilide, m-xylene, and toluene. Chen et al. (5) also reported degradation of butachlor by soil microbes. Six metabolites were identified: 2',6'diethylacetanilide, 2-hydroxy, 2-chloro, and N-methyl-2chloro derives of 2 ',6'-diethylacetanilide, 2,6-diethylanilide, $\mathrm{N}$-chloroacetyl-7- ethyl-2,3-dihydroindole.

Butachlor is structurally similar to several other widely used chloracetamide herbicides (alachlor, metalochlor, and acetochlor). Alachlor, metalochlor, and acetochlor have been classified as B-2 carcinogens by the U. S. Environmental Protection Agency (6-7). The Commission of the European Community has classified alachlor among their "high priority pesticides" (8). The USEPA (6) has set the maximum contaminant level of alachlor in drinking water at $2 \mu \mathrm{g} \mathrm{L}^{-1}$. Chloracetamideherbicidedegradation products aregenerally of lower molecular weight and more oxidized than the parent compound, therefore, they may be more water soluble, more mobile, and have a greater potential to leach (9-11). Somich et al. (12) reported that alachlor was dechlorinated upon UV irradiation and formed a number of intermediates that retained the aromatic ring and carbonyl carbons. Photoproducts included hydroxyalachlor, norchloralachlor, 2',6'diethyl- acetanilide, 2-hydroxyl-2',6'-diethyl- $\mathrm{N}$-methylacet- 
TABLE 1. Photoproducts of Butachlor

mass spectral data

\begin{tabular}{|c|c|c|c|c|c|c|c|c|}
\hline peak & $M W^{a}$ & $\mathbf{B P b}$ & \multicolumn{4}{|c|}{ secondary ions } & $\begin{array}{l}\text { retention } \\
\text { time (min) }\end{array}$ & compound \\
\hline 1 & 149 & 134 & 77 & 91 & 119 & 149 & 4.46 & 2, 6-diethylaniline \\
\hline 2 & 189 & 174 & 128 & 146 & 160 & 189 & 6.90 & 1-acetyl-7-ethylindole \\
\hline 3 & 263 & 146 & 132 & 164 & 174 & 189 & 7.66 & butachlor related \\
\hline 4 & 277 & 178 & 57 & 161 & 162 & 220 & 7.99 & $N$-(2,6-diethylphenyl)-N-(butoxymethyl)acetamide \\
\hline 5 & 291 & 57 & 41 & 81 & 188 & 217 & 8.25 & 2-oxo- $N$-(2,6-diethylphenyl)- $N$-(butoxymethyl)acetamide \\
\hline 6 & 291 & 160 & 146 & 174 & 176 & 218 & 8.40 & 1-hydroxyacetyl-2-butoxyl-3-methyl-7-ethylindole \\
\hline 7 & 275 & 174 & 57 & 146 & 186 & 201 & 8.52 & 8-ethyl-1-butoxymethyl-4-methyl-2-oxo-1,2,3,4-tetrahydroquinoline \\
\hline 8 & 275 & 218 & 57 & 134 & 144 & 201 & 8.62 & butachlor related \\
\hline 9 & 293 & 57 & 148 & 160 & 176 & 188 & 8.95 & 2-hydroxy-2',6'-diethyl-N-(butoxymethyl)acetanilide \\
\hline 10 & 275 & 57 & 174 & 189 & 201 & 202 & 9.03 & 1-acetyl-2-butoxyl-3-methyl-7-ethylindole \\
\hline 11 & 275 & 174 & 57 & 188 & 218 & 260 & 9.14 & butachlor related \\
\hline 12 & 311 & 57 & 160 & 176 & 188 & 237 & 9.25 & butachlor \\
\hline
\end{tabular}

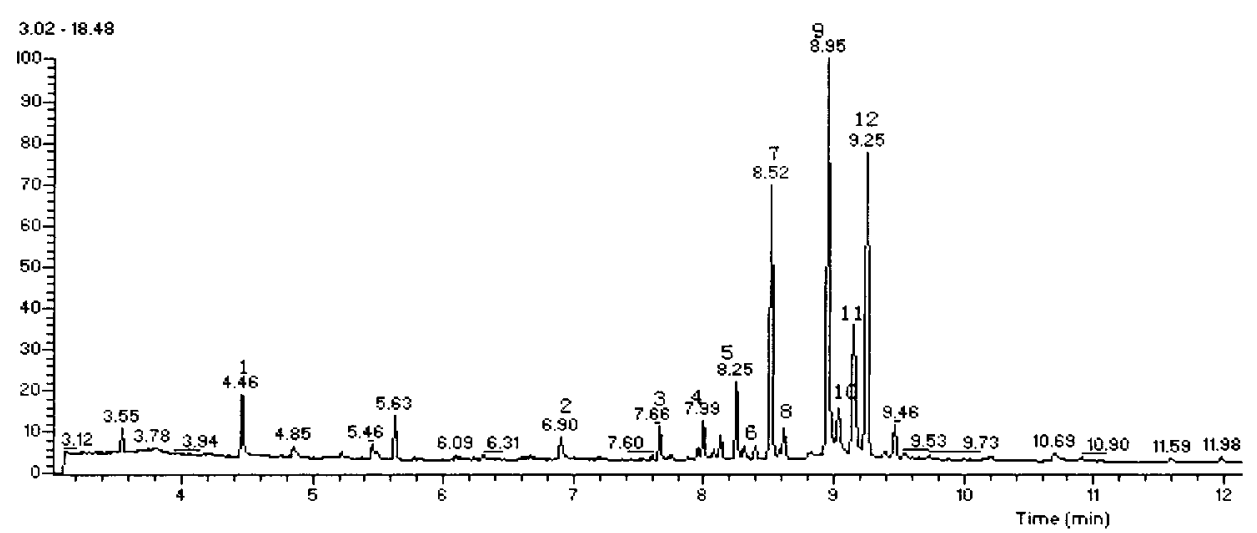

FIGURE 4. Typical GC/MS chromatogram of the photolysis experiments.

anilide, and a lactam. Penuela and Barcelo (13) reported that alachlor gave five photoproducts after UV irradiation. Three photoproducts were unequivocally identified corresponding to 2-hydroxyl-2',6'-diethyl-N-methylacetanilide, 8-ethyl-1methoxymethyl-4-methyl-2-oxo-1,2,3,4-tetrahydroquinoline, and hydroxyalachlor. Two photoproducts wereidentified by GC-MS, but their chemical structures are unknown. Mathew and Khan (14) found that hydroxylation, dehalogenation, oxoquinoline formation, and demethylation were the main processes during the photodegradation of metolachlor. Kochany and Maguire (15) found that photoproducts of metolachlor in water resulted from dechlorination, hydroxylation, dehydrochlorination with subsequent morpholine ring formation, and $\mathrm{N}$-dealkylation. Chiron et al. (16) reported that 14 photoproducts resulted from alachlor dechlorination with subsequent hydroxylation and cyclization processes. Thetwo major photoproducts were identified as hydroxyalachlor and 8-ethyl-1-methoxymethyl-4-methyl2-oxo-1,2,3,4-tetrahydroquinoline. Wilson and Mabury (17) found that monochloroacetic acid was a major photoproduct of alachlor, metolachlor, and butachlor in synthetic field water. Sunlight photodegradation of metolachlor was found slow in aqueoussolution, 6-8\% in a month (18-19). Alachlor and metolachlor each possessa long hydrolysishalf-life(16). According to Potter and Carpenter (20), ground water samples collected beneath a Massachusetts corn field were analyzed by gas chromatography/mass spectrometry (GC/MS). Twenty compounds were detected whose MS data indicated that they were derived from alachlor, presumably via environmental degradation. Somepublished data (21) haveindicated that degradation, in particular, cleaveage of alachlor's $\mathrm{N}$-methoxylmethyl group, contributes to detoxification. But other studies haveindicated that at least one of the residues, 2,6-diethylaniline, is a promutagen (22).
In this paper, photolysis and hydrolysis of butachlor in water were studied. We report the results of GC/MSanalyses of UV photoproducts and of hydrolysis products of the herbicide in water. Eleven compounds were identified; for nine compounds chemical structures were presumed.

\section{Materials and Methods}

Materials. Butachlor of $99.5 \%$ (analytical referencestandard) was obtained from the M onsanto Company (St. Louis, MO). Methanol was analytical-reagent grade and purified by redistillation. Supplies of paddy water from a Beijing Haidian ricefield and river water from the Jingmi canal which irrigated theBeijing Haidian rice field werefiltered with a microporous funnel (4G) prior to use. Other chemicals were of reagent gradeand were obtained from various commercial suppliers.

Photolysis. Irradiations were carried out using a 100-W medium-pressure quartz mercury vapor lamp (produced by Beijing Electric Light Source Institute) as the UV irradiation source. The lamp was immersed inside a quartz glass immersion well through which cold tap water flowed to keep the lamp cool. A butachlor aqueous solution in a quartz test tube was irradiated for $40 \mathrm{~min}$. The emission spectrum of the light source is shown in Figure 2. The light intensity is $658 \mu \mathrm{W} / \mathrm{cm}^{2}$ (ZDZ-1 UV irradiation photometer, $254 \mathrm{~nm}$ ). Thewholewater samples were extracted into petroleum ether and concentrated, then analyzed by GC/MS to determine the products of photodegradation.

Hydrolysis. Buffer solutions were prepared with $0.9 \mathrm{~g}$ of $\mathrm{Na}_{2} \mathrm{HPO}_{4} \cdot 12 \mathrm{H}_{2} \mathrm{O}$ dissolved into $1000 \mathrm{~mL}$ of distilled water. The pHs of buffer solutions were adjusted to 4,7 , or 10 by adding appropriate concentrations of $\mathrm{NaOH}$ or $\mathrm{H}_{3} \mathrm{PO}_{4}$ solution. The buffer solutions were sterilized at $121^{\circ} \mathrm{C}$ for 30 min. Butachlor aqueous solutions $\left(20 \mathrm{mg} \mathrm{L}^{-1}\right)$ were prepared 
at $\mathrm{pH} \mathrm{4,7,} \mathrm{and} 10$ using the buffer solutions, respectively. Butachlor aqueous solutions were placed in an incubator at $25 \pm 1{ }^{\circ} \mathrm{C}$ without light. Samples were taken at intervals of time for butachlor analysis by HPLC. After 265 days, the sample of butachlor aqueous solution at $\mathrm{pH} 4$ was analyzed by $\mathrm{GC} / \mathrm{MS}$ to determine the products of hydrolysis.

HPLC-UV. An LC-6A high-performance liquid chromatograph was equipped with a Shimadzu spectrophotometric detector for HPLC-UV analyses. A stainless steel column $(25 \mathrm{~cm} \times 4.6 \mathrm{~mm}$ i.d.) was packed with DuPont ODS chemically bonded phase, particle size $10 \mu \mathrm{m}$, and was pretested by the manufacturer. The detection wavelength of $215 \mathrm{~nm}$ was selected for all measurements for butachlor. The mobile phase was methanol/ water (80:20, v/ v) at a flow rate of $1.0 \mathrm{~mL} \mathrm{~min}^{-1}$. The retention time of butachlor was $11.0 \mathrm{~min}$.

Gas Chromatography. Analyses were performed using a Finnigan Trace gas chromatograph (2000 series) coupled with a Finnigan Voyager mass spectrometer detector (MSD), and Xcal ibur Chemstation. A $15 \mathrm{~m} \times 0.25 \mathrm{~mm}$ i.d. RTX- 5 column (0.25- $\mu \mathrm{m}$ film thickness) was used under the following temperature conditions: initial temperature at $50^{\circ} \mathrm{C}, 20^{\circ} \mathrm{C}$ $\mathrm{min}^{-1}$ at $200^{\circ} \mathrm{C}, 10^{\circ} \mathrm{C} \mathrm{min}^{-1}$ at $280^{\circ} \mathrm{C}, 3 \mathrm{~min}$ final hold. The inlet temperature was $250^{\circ} \mathrm{C}$. The helium carrier gas flow

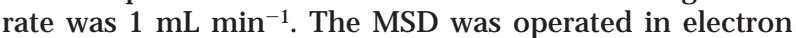
impact mode with detection voltage of $350 \mathrm{~V}$ and a source temperature of $200^{\circ} \mathrm{C}$, in full scan mode from m/ z 30 to 500 .

\section{Results and Discussion}

Photodegradation. Asolution of butachlor wasscanned using a Shimadzu DU-650 spectrophotometer. Butachlor's main absorbance wavelength is less than $280 \mathrm{~nm}$ (Figure 3). I t was indicated that photodegradation of butachlor was mainly caused by absorbance of ultraviolet light less than $280 \mathrm{~nm}$ wavelength. Considering that onlylittlesolar radiation below $300 \mathrm{~nm}$ reaches the earth's surface because of the protective shield of ozone in the stratosphere, sunlight photodegradation of butachlor must be slow. To study the photolysis mechanism and identify as many photoproducts as possible in a short time, a 100-W medium-pressure quartz mercury vapor lamp was used in our laboratory studies even though the conditions are different from actual environmental sunlight.

The natural logarithm values of the ratio of the initial concentation to the concentration at a given time (t) vs time were plotted and the (pseudo-fist-order) rate constants ( $k$ ) were determined by calculating the slope of theline; half-life $\mathrm{t}_{1 / 2}$ was calculated by $\ln 2 / \mathrm{k}$. The half-lives of butachlor at an initial concentration of $20 \mathrm{mg} / \mathrm{L}$ were $7.54,10.56$, and 12.22 min in deionized water, river water, and paddy water, respectively.

When exposed to UV light, butachlor in aqueous solution was rapidly degraded, giving at least 11 photoproducts (Table 1). After irradiation for $40 \mathrm{~min}$, the major photoproducts were compounds $\mathbf{9}, \mathbf{7}$, and $\mathbf{1 1}$, and minor photoproducts were compounds $\mathbf{1}, \mathbf{5}, \mathbf{1 0}, \mathbf{4}, \mathbf{3}, \mathbf{2}$, and $\mathbf{6}$. A typical GC/MS chromatogram of the photolysis experiments is shown in Figure 4. The mass spectra of compounds $\mathbf{1 - 1 2}$ are shown in Figure 5. Compound $\mathbf{1 2}$ is the parent butachlor, the structures of compounds $\mathbf{3}$ and $\mathbf{8}$ are unknown. It should be noted that structural assignments shown for those compounds are tentative: their full identification is still under investigation and may require other analytical methods such as NMR after an isolation step. Photoproducts correspond mainly to dechlorination of butachlor. Spectra of the presumed photoproducts were compared with literature data, when available.

Compound 1, with molecular weight (MW) 149, may correspond to 2,6-diethylaniline. Retention time is $4.46 \mathrm{~min}$. Observing the spectrum, molecular $\mathrm{M}^{+}$(149) could lose $\mathrm{CH}_{3}$ to give the base ion peak at $\mathrm{m} / \mathrm{z} 134$, and two $\mathrm{CH}_{3}$ to give the ion at $\mathrm{m} / \mathrm{z}$ 119. Compound $\mathbf{1}$ matches with previous spectra of photoproduct of alachlor from Potter and Carpenter (20) and Mangiapam et al. (23).

Compound 2, MW 189, may correspond to 1-acetyl-7ethylindole. Retention time is $6.90 \mathrm{~min}$. Observing the spectrum, molecular ion $\mathrm{M}^{+}$(189) could lose $\mathrm{CH}_{3}$ to give the base ion peak at $\mathrm{m} / \mathrm{z} 174, \mathrm{CH}_{3} \mathrm{CH}_{2}$ to give the ion at $\mathrm{m} / \mathrm{z} 160$, and $\mathrm{CH}_{3} \mathrm{CO}$ to give the ion at $\mathrm{m} / \mathrm{z} 146$. The compound was not reported before.

Compound 4, with MW 277, may correspond to N-(2,6diethylphenyl)- $\mathrm{N}$-(butoxymethyl) acetamide. Retention time is $7.99 \mathrm{~min}$. Theions at $\mathrm{m} / \mathrm{z} 220$ and 203 probably result from loss of $\mathrm{C}_{4} \mathrm{H}_{9}$ and $\mathrm{C}_{4} \mathrm{H}_{9} \mathrm{OH}$, respectively. The molecular ion could lose $\mathrm{C}_{4} \mathrm{H}_{9}$ and $\mathrm{CH}_{2} \mathrm{CO}$ (one $\gamma \mathrm{H}$ rearrange) to give the base peak ion at $\mathrm{m} / \mathrm{z} 178$. The base peak ion could lose $\mathrm{OH}$ to give the ion at $\mathrm{m} / \mathrm{z} 161$. The ion at $\mathrm{m} / \mathrm{z} 57$ is $\mathrm{C}_{4} \mathrm{H}_{9}{ }^{+}$peak. The mass spectrum of $\mathbf{4}$ is similar to that of $\mathrm{N}-(2,6-$ diethylphenyl)- $\mathrm{N}$-(methoxymethyl)acetamide, which is one of the metabolites of alachlor $(20,23)$.

Compound 5, M W 291, may correspond to 2-oxo-N- (2,6diethylphenyl)-N-(butoxymethyl)acetamide. Retention time is $8.25 \mathrm{~min}$. The base ion peak at $\mathrm{m} / \mathrm{z} 57$ is $\mathrm{C}_{4} \mathrm{H}_{9}{ }^{+}$peak. The molecular ion could lose $\mathrm{C}_{4} \mathrm{H}_{9} \mathrm{OH}$ to give the ion at $\mathrm{m} / \mathrm{z} 217$, and $\mathrm{CHO}$ to give the ion at $\mathrm{m} / \mathrm{z} 188$. The mass spectrum of 5 is similar to that of 2-oxo- $\mathrm{N}$-(2,6-diethyl phenyl)- $\mathrm{N}$-(methoxymethyl) acetamide which is one of the metabolites of alachlor (23).

Compound 6, with MW of 291, may correspond to 1-hydroxyacetyl-2-butoxyl-3-methyl-7-ethylindole. Retention time is $8.40 \mathrm{~min}$. The molecular ion could lose $\mathrm{C}_{4} \mathrm{H}_{9} \mathrm{O}$ to give theion at $\mathrm{m} / \mathrm{z} 218$, and $\mathrm{C}_{4} \mathrm{H}_{9} \mathrm{OH}$ to give the ion at $\mathrm{m} / \mathrm{z}$ 217. The molecular ion could lose $\mathrm{C}_{4} \mathrm{H}_{9} \mathrm{O}$ and $\mathrm{COCHOH}$ (one $\gamma \mathrm{H}$ rearrange) to give the base peak ion at $\mathrm{m} / \mathrm{z} 160$, and $\mathrm{C}_{4} \mathrm{H}_{9}$ and $\mathrm{COCHOH}$ to give the ion at $\mathrm{m} / \mathrm{z}$ 176. The molecular ion could lose $\mathrm{C}_{4} \mathrm{H}_{9} \mathrm{OCH}$ and $\mathrm{COCH}_{2} \mathrm{OH}$ to give the ion at $\mathrm{m} / \mathrm{z}$ 146. The compound has not been reported in previous literature.

Compound 7, with a molecular weight of 275, may correspond to 8-ethyl-1-butoxymethyl-4-methyl-2-oxo1,2,3,4-tetrahydroquinoline. Retention time is $8.52 \mathrm{~min}$. The molecular ion could lose $\mathrm{C}_{4} \mathrm{H}_{9} \mathrm{OH}$ to give the ion at $\mathrm{m} / \mathrm{z} 201$, and lose $\mathrm{C}_{4} \mathrm{H}_{9} \mathrm{OCH}_{2}$ to give theion at $\mathrm{m} / \mathrm{z}$ 188. Theion at $\mathrm{m} / \mathrm{z}$ 188 could lose two $\mathrm{H}$ to give the ion at $\mathrm{m} / \mathrm{z} 186$, and lose $\mathrm{CH}_{2}$ to give the ion at $\mathrm{m} / \mathrm{z} 174$, and lose $\mathrm{COCH}_{2}$ to give the ion at $\mathrm{m} / \mathrm{z}$ 146. The mass spectrum of compound $\mathbf{6}$ is similar to that of 8-ethyl-1-methoxymethyl-4-methyl-2-oxo-1,2,3,4tetrahydroquinoline, which is one of the photoproducts of alachlor (13).

Compound 9, with MW 293, may correspond to 2-hydroxy2',6'-diethyl- $\mathrm{N}$-(butoxymethyl)acetanilide. Retention timeis $8.95 \mathrm{~min}$. The base ion peak at $\mathrm{m} / \mathrm{z} 57$ is the $\mathrm{C}_{4} \mathrm{H}_{9}{ }^{+}$peak. The ions at $\mathrm{m} / \mathrm{z} 236,219,188$, and 160 may correspond to loss of $\mathrm{C}_{4} \mathrm{H}_{9} ; \mathrm{C}_{4} \mathrm{H}_{9} \mathrm{OH} ; \mathrm{C}_{4} \mathrm{H}_{9} \mathrm{OH}$ and $\mathrm{CH}_{2} \mathrm{OH}$; and $\mathrm{C}_{4} \mathrm{H}_{9} \mathrm{OH}$ and $\mathrm{COCH}_{2} \mathrm{OH}$ from the molecular ion, respectively. The mass spectrum of $\mathbf{9}$ is similar to that of 2-hydroxy-2',6'-diethyl$\mathrm{N}$-(methoxymethyl) acetanilide, which is one of the photoproducts of alachlor (13).

Compound 10 , with a molecular weight of 275 , may correspond to 1-acetyl-2-butoxyl-3-methyl-7-ethylindole. Retention time is $9.03 \mathrm{~min}$. The base ion peak at $\mathrm{m} / \mathrm{z} 57$ is $\mathrm{C}_{4} \mathrm{H}_{9}{ }^{+}$. Theion at $\mathrm{m} / \mathrm{z} 201,189,174$, and 146 may correspond to loss of $\mathrm{C}_{4} \mathrm{H}_{9} \mathrm{OH} ; \mathrm{C}_{4} \mathrm{H}_{9} \mathrm{OCH} ; \mathrm{C}_{4} \mathrm{H}_{9} \mathrm{OCH}$ and $\mathrm{CH}_{3}$; and $\mathrm{C}_{4} \mathrm{H}_{9}$ $\mathrm{OCH}$ and $\mathrm{COCH}_{3}$ from the molecular ion, respectively. The compound has not been reported in previous literature.

The mass spectrum of compound $\mathbf{1 1}$ showed a molecular ion peak at $\mathrm{m} / \mathrm{z} 275$, and ion peaks at $\mathrm{m} / \mathrm{z} 260,218,188$, and 174, which correspond to loss of $\mathrm{CH}_{3}, \mathrm{C}_{4} \mathrm{H}_{9}, \mathrm{C}_{4} \mathrm{H}_{9} \mathrm{OCH}_{2}$, and $\mathrm{C}_{4} \mathrm{H}_{9} \mathrm{OCH}_{2}$ and $\mathrm{CH}_{2}$, respectively. Retention timeis $9.14 \mathrm{~min}$. The compound was not reported before. We found that compound $\mathbf{1 1}$ was transformed to compound $\mathbf{9}$ when the extracted sample was placed for a few days. Compound $\mathbf{1 1}$ 

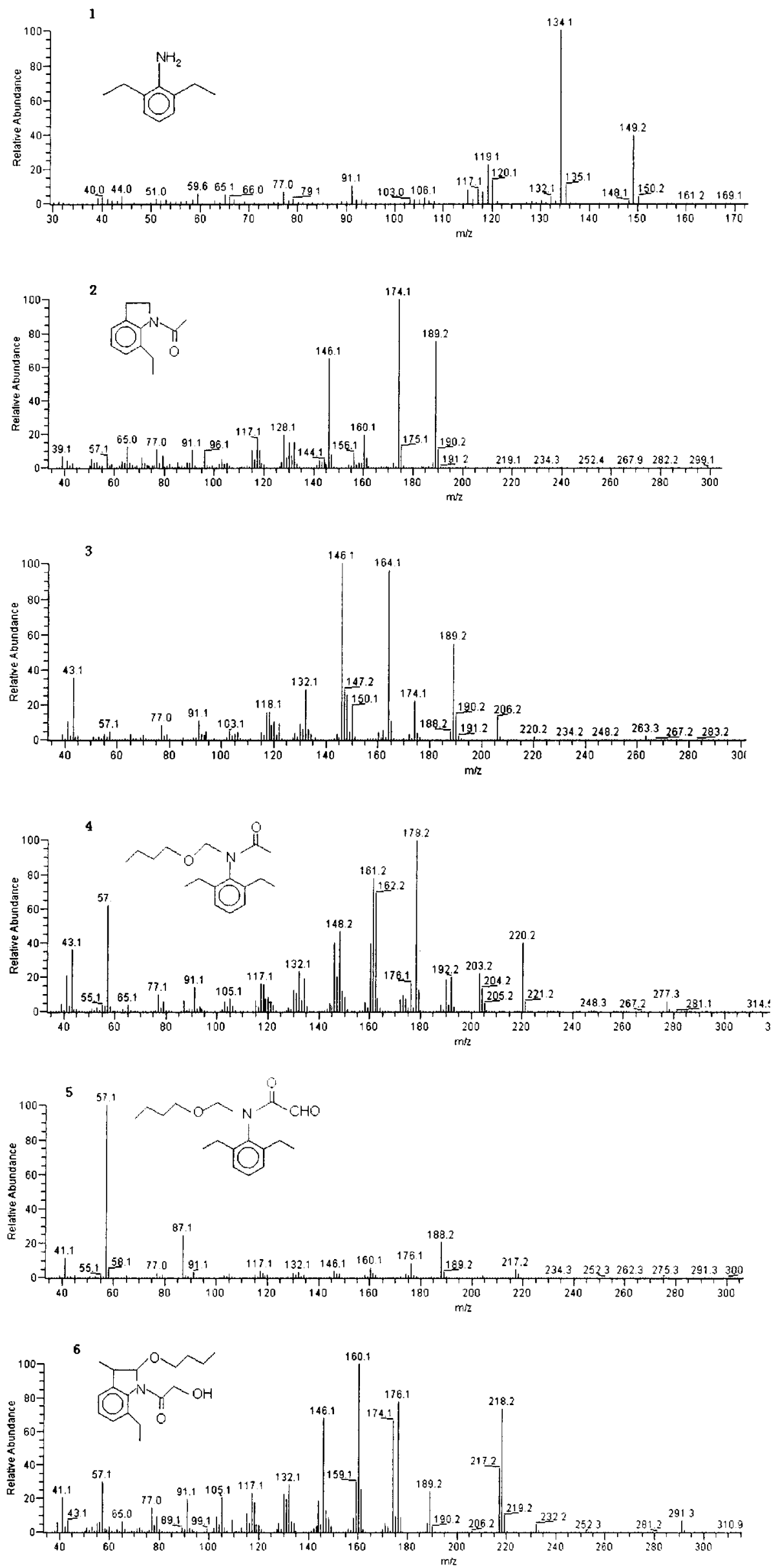

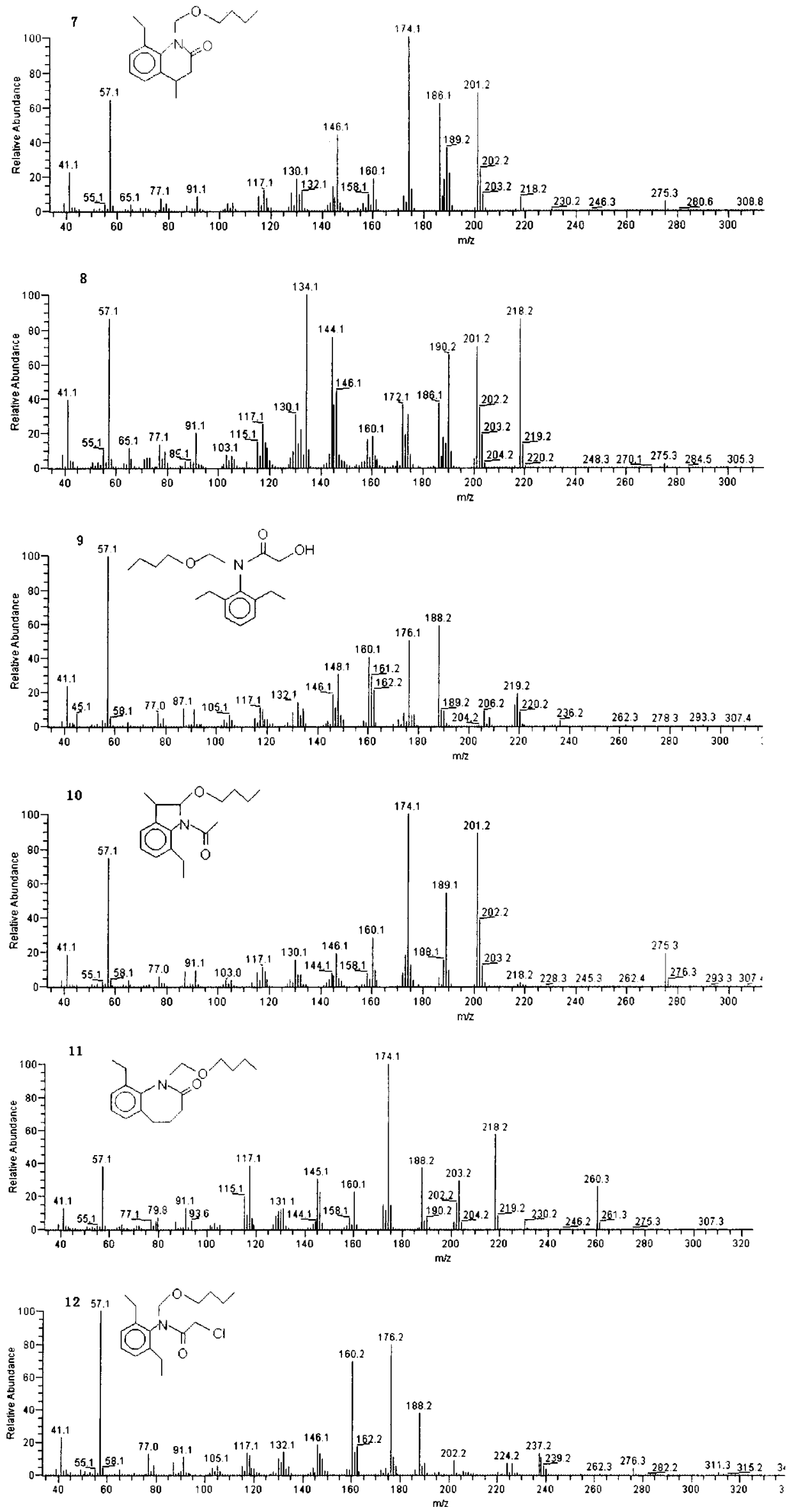

FIGURE 5. GC/MS spectra and presumed chemical structures of metabolites.

VOL. 35, NO. 14, 2001 / ENVIRONMENTAL SCIENCE \& TECHNOLOGY • 2893 

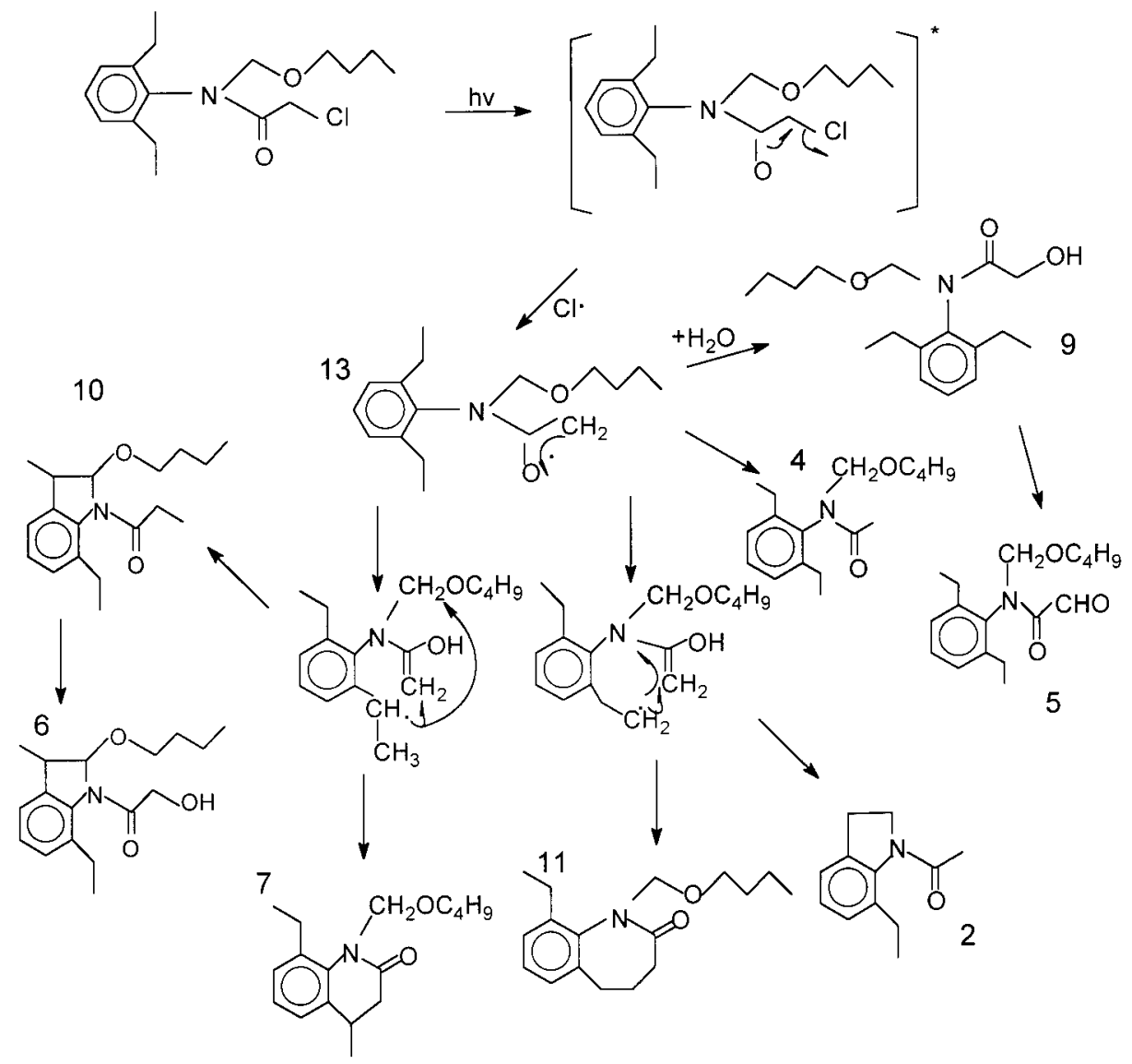

FIGURE 6. Presumed mechanism of butachlor photodegradation.

may be not stable enough and reacted with $\mathrm{H}_{2} \mathrm{O}$ cleaving the cycle to form $\mathbf{9}$.

Comparing with the standard mass spectrum of butachlor, the probability of compound $\mathbf{1 2}$ corresponding to butachlor is $97.4 \%$. Its retention time is $9.25 \mathrm{~min}$. The ion at $\mathrm{m} / \mathrm{z} 276$, $237,188,176$, and 160 may correspond to loss of $\mathrm{Cl}, \mathrm{C}_{4} \mathrm{H}_{9} \mathrm{OH}$; $\mathrm{C}_{4} \mathrm{H}_{9} \mathrm{OH}$ and $\mathrm{CH}_{2} \mathrm{Cl} ; \mathrm{C}_{4} \mathrm{H}_{9}$ and $\mathrm{H}$ and $\mathrm{COCH}_{2} \mathrm{Cl}$; and $\mathrm{C}_{4} \mathrm{H}_{9} \mathrm{OH}$ and $\mathrm{COCH}_{2} \mathrm{Cl}$ from the molecular ion. The base ion peak at $\mathrm{m} / \mathrm{z} 57$ is $\mathrm{C}_{4} \mathrm{H}_{9}{ }^{+}$.

We presumed that the molecular weight of compound $\mathbf{3}$ is 263 and the molecular weight of compound $\mathbf{8}$ is 275 . No structure could be attributed with certainty to either compound $\mathbf{3}$ or compound $\mathbf{8}$.

In our studies, dechlorination is presumably the first step of photodegradation of butachlor in water when irradiated with UV light. Absorption of a photon by the carbonyl of butachlor is followed by loss of chlorine at the a-carbon, affording intermediate compound $\mathbf{1 3}$. Intermediate compound $\mathbf{1 3}$ proceeds to a hydroxylation process or a cyclization process to give various photoproducts. Compound $\mathbf{1}$ may be formed by other photoproducts proceeding to degrade. Figure 6 shows a mechanism of butachlor photodegradation.

However, according to Wilson and Mabury's (17) investigation, monochloroacetic acid was a major photoproduct of chloroacetanilide herbicides in synthetic field water. But monochloroacetic acid has not been detected in our studies. Maybe monochloroacetic acid was neglected because of our analytical method limitation, as monochloroacetic acid is a strong polar product. Monochloroacetic acid may beformed on another pathway of photodegradation (17). It should be noted that photolysis rates and photoproduct formation are actually dependent on the intensity and the wavelength distribution of the light used. The photodegradation mechanism and products of butachlor in our study are not all the same as sunlight photodegradation under natural environmental conditions.
Hydrolysis. The kinetics process of butachlor can also be described by the first-order reaction equation. The experimental results indicated that $\mathrm{H}^{+}$can accelerate butachlor hydrolysis. The rateconstant $k$ values of butachlor hydrolysis were $1.1 \times 10^{-3}, 6 \times 10^{-4}$, and $6 \times 10^{-4} \mathrm{~d}^{-1}$ in $\mathrm{pH} 4,7$, and 10 aqueous solutions, respectively. The half-life of butachlor

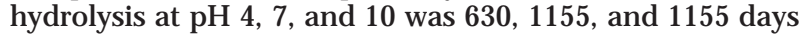
at $25^{\circ} \mathrm{C}$ respectively. Butachlor possesses a long hydrolysis half-life. A hydrolysis product at $\mathrm{pH} 4$ was identified to be compound 9[2-hydroxy- 2 ',6'-diethyl- $\mathrm{N}$-(butoxymethyl) acetanilide]. Retention time of hydrolysis product is $8.95 \mathrm{~min}$. Dechlorination is regarded as a route of hydrolysis. The hydrolysis pathway is still not well elucidated because of the likely formation of the highly polar product monochloroacetic acid, and their extraction from water remainsa difficult topic.

\section{Conclusions}

Eleven degradation products of butachlor were identified by GC/ MS after photolysis and hydrolysis in water. Compound 9[2-hydroxy-2',6'-diethyl-N-(butoxymethyl) acetanilide] was found to bea common product in photolysis and hydrolysis. Major photoproducts are compounds 9, 7, and $\mathbf{1 1}$. Dechlorination is presumably thefirst step of photodegradation of butachlor and is followed by either hydroxylation or cyclization. Hydrolysis of butachlor is a slow process and dechlorination is a route of hydrolysis. The half-life of butachlor hydrolysis at $\mathrm{pH} \mathrm{4,7,} \mathrm{and} 10$ was 630, 1155, and 1155 days at $25^{\circ} \mathrm{C}$ respectively. However, when exposed to UV light, butachlor in aqueous solution was rapidly degraded, the half-lives at initial concentration of $20 \mathrm{mg} \mathrm{L}^{-1}$ butachlor were only $7.54,10.56$, and $12.22 \mathrm{~min}$ in deionized water, river water, and paddy water, respectively.

\section{Acknowledgments}

This work was supported by the National Natural Science Foundation of China (No. 29837170). Wethank Huajun Chen 
from Beijing Forestry University for giving valuable suggestions for GC/MS analyses.

\section{Literature Cited}

(1) Hu, X. Nongyao (China) 1998, 37, 7-11.

(2) Wang, L. Nongyao (China) 1999, 38, 1-8.

(3) Chen, Y. L.; Chen, C. C. Nippon Noyaku Gakkaishi (Engl.) 1978, 3 (2), 143-148.

(4) Chen, Y. L.; Lo, C. C.; Wang, Y. S. Nippon Noyaku Gakkaishi (Engl.) 1982, 7 (1), 41-45

(5) Chen, Y. L.; Wu, T. C. Nippon Noyaku Gakkaishi (Engl.) 1978, 3 (4), 411-417.

(6) U.S. EPA. Drinking Water Regulations and Health Advisories; Lewis Publishers: Chelsea, MI, 1990.

(7) U.S. EPA. Questions and Answers. Conditional Registration of Acetochlor; Office of Prevention, Pesticides and Toxic Substances, U.S. EPA: Washington, D. C., March 11, 1994; 18 pp.

(8) Fielding, M., Ed. Pesticidesin Ground and DrinkingWater (Water Pollution Research Report 27); Commission of the European Communities: E. Guyot SA, Brussels, 1992.

(9) Malcomber, C.; Bushway, R.; Perkin, L.; Baker, D.; Fan, D. S.; Fergurson, B. S. J. Agric. Food Chem. 1992, 40, 1450-1452.

(10) Koplin, D. W.; Goolsby, D. A.; Aga, D. S.; Iverson, J. L.; Thurman, E. M. U. S. Geol. Surv. Water-Supply Pap. 1994, 2413.

(11) Kolpin, D. W.; Nations, B. K.; Goolsby, D. A.; Thurman, E. M. Environ. Sci. Technol. 1996, 30, 1459-1464.

(12) Somich, C. J.; Kearney, P. C.; Muldoon, M. T.; Elsasser, S. J. Agric. Food Chem. 1988, 36, 1322-1326.

(13) Penuela, G. A.; Barcelo, D. J. Chromatogr. 1996, 754, 187-195.
(14) Mathew, R.; Khan, S. U. J. Agric. Food Chem. 1996, 44, 39964000.

(15) Kochany, J.; Maguire, R. J. J. Agric. Food Chem. 1994, 42, 406412.

(16) Chiron, S.; Abian, J.; Ferrer, M.; Sanchez-Baeza, F.; Messeguer A.; Barcelo, D. Environ. Toxicol. Chem. 1995, 8, 1287-1298.

(17) Wilson, R. I.; Mabury, S. A. J. Agric. Food Chem. 2000, 48, 944950.

(18) LeBaron, H. M.; M cFarland, J. E.; Simoneaux, B. J.; Ebert, E. In Herbicides: Chemistry, Degradation and Mode of Action; Kearney, P. C., Kaufman, D. D., Eds.; Dekker: New York, 1988; Vol. 3, pp 335-382.

(19) Chesters, G.; Simsiman, G. V.; Levy, J.; Alhajjar, B. J.; Fathulla, R. N.; Harkin, J. M. Rev. Environ. Contam. Toxicol. 1989, 110, $1-74$.

(20) Potter, T. L.; Carpenter, T. L. Environ. Sci. Technol. 1995, 29, 1557-1563.

(21) Jacobsen, N. E.; Sanders, M.; Toia, R. F.; Casida, J. F. J. Agric Food Chem. 1991, 39, 1342-1350.

(22) Kimmel, E. C.; Casida, J. C.; Ruzo, L. O. J. Agric. Food Chem. 1986, 34, 157-161.

(23) Mangiapam, S.; M benfenati, E.; Grasso, P. Environ. Sci. Technol. 1997, 31, 3637-3646.

Received for review September 19, 2000. Revised manuscript received February 23, 2001. Accepted April 19, 2001.

ES0016811 